\title{
Research on the Teaching Reform of Computer Composition Principle in CDIO Mode
}

\author{
Le Wei ${ }^{1, a}$, Qiuyun Zhao ${ }^{1, b}$ \\ ${ }^{1}$ School of Computer, Chengdu University of Information Technology, Chengdu, China \\ aweile@cuit.edu.cn, bzqyuen@cuit.edu.cn
}

\begin{abstract}
Keywords: engineer education; composition principle of computer; mind map; assisted instruction; software simulation

Abstract. For existing problems and with guidance of CDIO, teaching of the Computer Composition Principle is reformed from teaching objectives, methods, the experimental teaching and assessment. Application of mind map, the auxiliary teaching platform, and the software simulation application are discussed in teaching. Besides, the score evaluating method is determined. And the teaching model, which aims to train students' ability, brings different teaching methods and combines theory with practice, is established. The new teaching model can improve the teaching quality and cultivate the ability of students to solve engineering problems.
\end{abstract}

\section{Introduction}

CDIO (Conceive, Design, Implement, Operate ) means the conception, design, implementation and operation, currently as a talent training concept of the international higher engineer education. It reflects the whole life process of the modern industrial products from the development idea to product working, improvement and the end, abandoned [1]. The core content of CDIO is a vision, an outline and 12 standards. Through new education patterns of Study in Practice and Teaching and Learning Based on Project [2], students are trained with emphasis on cultivating students engineering basic knowledge, personal ability, team interpersonal ability and systems engineering capability, creating suitable talents for modern society need. More students could be qualified with engineering professional ability, social consciousness and entrepreneurship and become innovation spirit engineers [3].

Composition Principle of Computer is an important professional basic course of the computer major. With a standalone system as the research object, the course focuses on explaining logic composition and working mechanism of the computer hardware system, sets up the whole concept of computer system, lays foundation of the computer hardware system analysis, development, application and design abilities [4].

Therefore, colleges and universities attach great importance to Composition Principle of Computer in talent cultivation. While according to the actual effect, endeavors did not reach the goal of the course. At the same time, taking the needs of the excellent engineer into account, research on the course teaching reform under the CDIO mode is of great significance for Composition Principle of Computer.

Based on this and under CDIO, problems in the Composition Principles of Computer are analyzed, the curriculum reform is researched from the teaching objectives, teaching methods, practice teaching and examination. And the feasible scheme is put forward.

\section{Current Problems}

Because Composition Principles of Computer plays an important role in the talent training, research on the course reform has not been stopped [5-8]. Although the reform has been engaged in the course, also a series of achievements have bean get, there are still some problems $t$ in the CDIO model of education, mainly reflected in:

(i) The lecture takes knowledge teaching as the target, but the students' ability cultivation is not enough. The indoctrination or the spoon-feeding teaching method is still very much. The bad 
teaching method focus on teaching but learning has not the guide and cultivation of the learning ability, problem analyzing and solving abilities.

(ii) It is still not improved that teaching emphasizes theory and lights practice. Teachers' teaching and students' learning both take attention to theory, contempt and even ignore the practice teaching, which can promote knowledge acquisition and ability training.

(iii) Evaluation for the lecture is unreasonable. The lecture is still lack of the scientific assessment indicators and the quantitative evaluation system. Usually evaluation based on the paper score pays attention to the result. The assessment result is unscientific and even unfair sometimes.

\section{Reform of the Course Teaching}

In view of the above questions, bold explorations have been carried on with the guidance of CDIO syllabus in Composition Principles of Computer. A set of the effective teaching modes have been summed up gradually for training students' four abilities. The modes were applied in 2013 and 2014 computer science and technology in Chengdu University of Information Technology, and satisfactory results were achieved.

Course training objectives with knowledge and ability. In accordance with the CDIO syllabus requirements and the course characteristics, the training objectives of the course have been reestablished, and three corresponding level indicators have been identified. Objectives are shown in table 1 . Differently from the past, new training objectives include not only knowledge goals, but also the ability ones.

Table 1 course training objectives

\begin{tabular}{|c|c|c|}
\hline $\begin{array}{l}\text { first-class } \\
\text { indicators }\end{array}$ & $\begin{array}{l}\text { second-class } \\
\text { indicators }\end{array}$ & third-class indicators \\
\hline \multirow{3}{*}{$\begin{array}{l}\text { Basic technology } \\
\text { knowledge }\end{array}$} & $\begin{array}{l}\text { Ability to use the basic } \\
\text { subject knowledge }\end{array}$ & $\begin{array}{l}\text { Ability to use the general physics and electronic } \\
\text { knowledge }\end{array}$ \\
\hline & \multirow{2}{*}{$\begin{array}{l}\text { Basic knowledge and } \\
\text { principles of the core } \\
\text { application engineer }\end{array}$} & $\begin{array}{l}\text { Mastering of the organization and architecture of } \\
\text { the computer system }\end{array}$ \\
\hline & & $\begin{array}{l}\text { Mastering of the basic theory, knowledge, } \\
\text { methods and skills of the computer software and } \\
\text { hardware }\end{array}$ \\
\hline \multirow{2}{*}{$\begin{array}{l}\text { Personal and } \\
\text { professional abilities }\end{array}$} & \multirow{2}{*}{$\begin{array}{l}\text { Scientific literacy and } \\
\text { professional ethics }\end{array}$} & $\begin{array}{l}\text { Mastering of the scientific thinking method and } \\
\text { research methods } \\
\text { The strong sense building of responsibility and } \\
\text { professionalism }\end{array}$ \\
\hline & & $\begin{array}{l}\text { Achievements of practicality, innovation and } \\
\text { rigorous scientific literacy, such as professional } \\
\text { ethics, integrity, and responsibility }\end{array}$ \\
\hline \multirow{3}{*}{ Interpersonal skills } & Team cooperation ability & $\begin{array}{l}\begin{array}{l}\text { Setting up the good team } \\
\text { consciousness }\end{array} \\
\end{array}$ \\
\hline & \multirow[b]{2}{*}{ Communication skills } & Having strong communication skills \\
\hline & & $\begin{array}{l}\text { Being successful at the effective communication } \\
\text { in written, electronic, charts, and verbal forms. }\end{array}$ \\
\hline $\begin{array}{l}\text { Abilities to } \\
\text { conceive, design, } \\
\text { implement, and } \\
\text { operate a system in a } \\
\text { social environment }\end{array}$ & $\begin{array}{l}\text { Systematic conception } \\
\text { and engineering }\end{array}$ & $\begin{array}{l}\text { Being able to design system objectives and } \\
\text { requirements, define functions, concepts and the } \\
\text { structure. }\end{array}$ \\
\hline
\end{tabular}

Several teaching methods. In order to achieve the course training goal, several traditional teaching methods were adopted, such as the demonstration teaching, heuristic teaching and question-answer teaching method. The new mind map and the auxiliary teaching platform were also introduced into teaching. Good results have been achieved.

(i) Using the appropriate teaching methods according to teaching content 
Whether old and new, good methods could achieve teaching effects and should be adopted. Appropriate teaching methods should be taken according to teaching contents. For example, the heuristic teaching method could be used to explain the information transmission control method. Teachers firstly propose that the I/O start time is very slow. Then it could be asked that what can be done by CPU after starting I/O. If CPU executes programs, it should be answered that how to inform CPU that the I/O is ready, and whether the hardware or software control transmission would be used. These issues are brought up so as to give three transmission ways, and specify that how to solve these problems in three ways. In teaching process, teachers should guide students to think actively, make them participate teaching, and then realize the view collision.

(ii) Application of the mind map

The mind map is a specific method of radioactive thinking. It uses rules of memory, reading, and thinking, shows the mutual relationship and membership between the different subject levels through the level chart with text and graphics. The mind map is used to improve the learning efficiency and the innovative thinking. In teaching of Composition Principles of Computer, students must draw the mind map for each lesson, each chapter. These help students strengthen their knowledge understanding, grasp the key and difficult points and establish the course knowledge system, and then improves the students' learning efficiency, comprehensive analysis ability and innovative thinking ability.

(iii) Making full use of the auxiliary teaching platform

The auxiliary teaching platform is a typical application of the internet technology in education. It plays an important role in the teaching resource sharing, improving teaching and learning communication between teachers and students, and the auxiliary classroom teaching. The platform could be bought from mature products, or be customized developing. Most of all, it should consider the course specific characteristics, set the school and course needs as the target all alone. Through practice, auxiliary platform of Composition Principles of Computer should has the question bank management, online test, test paper generation, release resources, job submission, performance management, course discussion, user management, rights management and information release etc. functions. Through the platform, teachers could input and maintain the examination question bank, generate the test paper according to the question content in the bank, release the course resources such as the courseware, teaching plans, lesson plans, teaching syllabus, etc., and set different priorities for resources. Teachers could also release each tasks and requirements, modify students' exercises, and give results. Teachers could publish the course information, answer questions raised by students, and participate in the related topics too. Students could download related resources, submit the relevant exercises, and choose different questions for online testing according to their own needs. They could ask teachers some questions, check the individual's usual. The auxiliary teaching platform breaks the space and time constraints, and has a positive effect on improving the teaching quality, improving students' ability and serving the teachers and students.

Promoting the practice teaching reform actively. In Composition Principles of Computer, it must be changed of the past concept, i.e. heavy theory, light practice. It is also not correct that students will not understand the actual computer design with poor theory. It also should be adjusted that students couldn't master the theory until saw the application of the theory in practice. Therefore, teaching contents should be designed reasonable. A good experimental platform should be built. Experiment examination should be executed strictly. Besides, the software simulation technology should be introduced into the practice teaching of Composition Principles of Computer creatively. The main approach is as follows.

(i) According to the course objectives, simple verification experiments are chosen, such as the arithmetic logic unit experiment, the static random access memory reading and writing experiment. Comprehensive design experiments are also exercised, such as the design and implementation of the simple model.

(ii) The experimental platform is determined to support not only the fixed simple experiment, but also the dynamic extension of the experimental project. 
(iii) Experiments of Composition Principles of Computer needs to be carried out by the experiment box, which occupy the class time on one hand. On the other hand students should encode the simulation programs, which take students' extracurricular time. For simple simulation programs, each student needs complete it independently. For complex simulation programs, students would be grouped into teams to do in coordination with team leaders and with reasonable work division and cooperation.

(iv) Each experiment should be strictly checked to ensure that everyone reaching objectives. In experimental reports, students are required to complete the data analysis and personal experience carefully.

Improvement the assessment criteria of the usual performance. The examination result of Composition Principles of Computer is composed of the usual performance evaluation and the paper test result. The usual performance is mainly according to the attendance and the experimental report evaluation. There are many problems, such as that the evaluation indicator is not perfect, the evaluation process is not scientific enough, the evaluation result is not quite reasonable and so on. Therefore, it is necessary to improve the usually performance assessment criteria. The improved criteria are shown in table 2.

Table 2 usual performance assessment criteria

\begin{tabular}{|c|c|c|}
\hline $\begin{array}{l}\text { examination } \\
\text { link }\end{array}$ & examination requirement & $\begin{array}{l}\text { Score } \\
\text { scale }\end{array}$ \\
\hline Attendance & $\begin{array}{l}\text { Absent once, deduct } 10 \text { points. Arriving late or leaving early } 1 \text { times, deduct } 5 \\
\text { points. Unexcused absences } 6 \text { or more times, disqualify the final exam. }\end{array}$ & $20 \%$ \\
\hline Expression & $\begin{array}{l}\text { According to the usual performance in questions, exercises, the class activities } \\
\text { and so on, give scores of students' performance score. }\end{array}$ & $10 \%$ \\
\hline Task & $\begin{array}{l}\text { According to the task execution, give each task evaluation by the criteria, the } \\
\text { average of multiple task results is the final task score. }\end{array}$ & $15 \%$ \\
\hline Test & $\begin{array}{l}\text { Use the online testing function on the auxiliary teaching platform to help } \\
\text { students consolidate knowledge. Get more than } 5 \text { test scores. }\end{array}$ & $15 \%$ \\
\hline \multirow{3}{*}{ Experiment } & $\begin{array}{l}\text { Experimental checking } \\
\text { Each experimental has the total score } 100 \text {. Adopt the inverse deduction } \\
\text { system. The deduction points are as follows. } \\
\text { (i) Experimental principle is not clear, can not grasp the principle of the } \\
\text { experiment involved. Deduct } 5 \text { to } 20 \text { points deduction. } \\
\text { (ii) Without the original data record forms, deduct } 5 \text { points. } \\
\text { (iii) Answering teachers' questions, random checks incorrectly, deduct } 5 \text { to } 20 \\
\text { points. } \\
\text { (iv) Depending on the specific circumstances of operation effect, deduct } 5 \text { to } \\
55 \text { points. }\end{array}$ & $15 \%$ \\
\hline & $\begin{array}{l}\text { Experiment reports } \\
\text { (i) If the handwriting is not correct or the arrangement is not neat, deduct } 5 \text { to } \\
20 \text { points. } \\
\text { (ii) If the content arrangement is not correct, deduct } 5 \text { to } 10 \text { points. } \\
\text { (iii) If the report content lacks any one of the experiment topic, the } \\
\text { experimental purpose, the experimental equipment, the content and the step, } \\
\text { the result analysis, deduct } 10 \text { points. The more missing, the more deduction. } \\
\text { (iv) If the report lacks the experimental principle or the experimental data, } \\
\text { deduct } 10 \text { points. The more missing, the more deduction. } \\
\text { (v) If the report is not submitted on time, deduct } 10 \text { to } 30 \text { points. }\end{array}$ & $15 \%$ \\
\hline & $\begin{array}{l}\text { Simulation program } \\
\text { Give the simulation program result according to the simulation program } \\
\text { function, style, the program actual effect . }\end{array}$ & $10 \%$ \\
\hline
\end{tabular}




\section{Conclusion}

In this paper, from the perspective of improving teaching quality and cultivating students' ability, problems in Composition Principles of Computer were analyzed according to the requirements of CDIO syllabus. On the basis of it, the course teaching mode of the course was studied in several aspects, such as the course objectives, teaching methods, practice teaching links, and the usual performance assessment. The study has been verified in actual teaching and achieved good results. The new teaching mode of Composition Principles of Computer reflects the characteristics of the basic, comprehensive, innovative characteristics, and fully mobilize the student learning enthusiasm .

\section{Acknowledgements}

This paper is supported by the school level excellent course project of Composition Principles of Computer of Chengdu University of Information Technology University. It is also the periodical achievement of the Computer Science and Technology ( TS2488 ), which is one of the fifth Education Ministry Institution characteristic specialties..

\section{References}

[1] H. M. TIAN, B. P. ZHU and A. P. CHEN: Experimental Technology and Management, Vol. 28 (2011), p. 130-132.(In Chinese)

[2] C. Y. LI, Z. K. TANG: Experimental Technology and Management, Vol. 28 (2011), p. 173-178.(In Chinese)

[3] J. R. LIU, M. H. WU and Z. P. LI: Experimental Technology and Management, Vol. 28 (2011), p. 154-156.(In Chinese)

[4] Q. Y. ZHAO, J. HE and L. WEI: Computer Knowledge and Technology, Vol. 4 (2008), p. 693-694.(In Chinese)

[5] F. H. YU, X. R. ZHU and T. ZHENG: The Chinese Journal of ICT in Education, (2012), p. 69-71.(In Chinese)

[6] H. WANG: Journal of Liaoning University of Technology(Social Science Edition), Vol. 17 (2015), p. 117-119.(In Chinese)

[7] Y. HE, J. M. ZHANG: Journal of Xinzhou Teachers University, Vol. 31 (2015), p. 25-28.(In Chinese)

[8] X. Y. JIANG, Y. CHEN: Experimental Technology and Management, Vol. 30 (2013), p. 162-165.(In Chinese) 